\title{
Firm Value Factors in the Mining Sector in Indonesia Stock Exchange
}

\author{
Sulastri ${ }^{*}$, Norma Dwi Kartika Sari ${ }^{2}$ \\ ${ }^{1,2}$ State University of Malang, Malang, Indonesia \\ *Corresponding author. Email: Sulastri.fe@um.ac.id
}

\begin{abstract}
This study aims to examine the effect of political connection and tax aggressiveness on firm value. This research is a quantitative research. Sampling method used in this research is purposive sampling with total of 22 companies' annual report data. Secondary data is being used which obtained from Indonesia Stock Exchange website (www.idx.com). Multiple regression is used to analyzing data. The result of this study implied that it is improper to use political connection as predictor variable that could affect the firm value. However, the tax aggressiveness could be used as predictor variable that could affect the firm value.
\end{abstract}

Keywords: Firm Value, Political Connection, Tax Aggressiveness.

\section{INTRODUCTION}

The main goal for go public company to increase or maximize the value of the company, because high company value can reflect the prosperity of the company owners and shareholders. Firm value is the investor's perception of the company [1]. The higher the firm value, investors will believe in the company's future prospects as well as the company's performance.

Basically, company value can be measured through several aspects, one of which is the company's stock price, because stock price shows the central assessment of marketers, therefore, the higher company's stock price in the market resulting in the higher of said company's value [2]. So, it can be concluded that the stock price is the right index to measure company value.

Volatility of stock prices in the market becomes an interesting phenomenon to discuss, as well as the case for stock prices in the mining sector which underwent bull rally in the 2016-2018 period. The growth in mining company stock caused by improvement in world oil prices in 2016 [3], while in 2017 the mining sector still received positive sentiment from world oil prices [4]. 2018 is a political campaign season that will affect the movement of the stock market, including the mining sector [5]
Table 1. Development of the Sectoral Stock Price Index for 2016-2018

\begin{tabular}{|l|c|c|c|}
\hline Tahun & $\mathbf{2 0 1 6}$ & $\mathbf{2 0 1 7}$ & $\mathbf{2 0 1 8}$ \\
\hline Agroindustry Sector & 1864 & 1616 & 1564 \\
\hline Mining Sector & 1384 & 1594 & 1776 \\
\hline $\begin{array}{l}\text { Basic Industry } \\
\text { Sector }\end{array}$ & 538 & 689 & 855 \\
\hline Other Sectors & 1371 & 1381 & 1394 \\
\hline Consumption Sector & 2324 & 2861 & 2569 \\
\hline Property Sector & 518 & 496 & 448 \\
\hline Infrastructure Sector & 1056 & 1184 & 1064 \\
\hline Financial Sector & 812 & 1141 & 1176 \\
\hline Trade Sector & 861 & 922 & 784 \\
\hline $\begin{array}{l}\text { Manufacturing } \\
\text { Sector }\end{array}$ & 1369 & 1640 & 1618 \\
\hline
\end{tabular}

Source: Indonesia Stock Exchange (http://www.idx.com/)

One of the methods to analyze stock prices' volatility is fundamental analysis in which the stock price is influenced by company's financial performance. Other than that, there are other external factors that could affect stock price. Those are political atmosphere of a country, government's policies, and various issues that affecting investor in trading shares [6]

External factors that can be analyzed to assess firm value are the political connections owned [7], [8], [9] and [10] who developed a signaling theory in which stating that the company will provide signals in the form of information to external parties regarding the company's prospects in the future. With the existence of political connections that the company has, it can 
simplify its operational activities, such as the ease of obtaining contracts or projects from the government [7]. So, it can be concluded that some of the advantages of a politically connected company can send a positive signal to external parties.

In addition, according to [11] politically connected companies can obtain debt funding by obtaining loan memos from the government. Political connections with government can be an informal protection mechanism in competitive markets imperfect for private companies, where legal protection and the economic environment are inadequate or unreliable in those markets [9]. Thus, companies with political connections will increase company value [8]. The results of the positive influence of political connections on firm value are in accordance with the research of [12], [13] and [14]. However, other research shows that political connections have no effect on firm value [15]. The difference in research results is likely due to the different research samples used. Based on exposition above, the hypothesis regarding the political connection to firm value is:

H1: Political connections have positive effect on firm value

In addition, another factor that can be analyzed to assess firm value is tax aggressiveness, [16], [17], [18], [19] and [20] who developed agency theory which stating that the asymmetry of information between management and shareholders resulting in agency conflict. This agency problem affecting the existence of tax planning actions [21]. The agent will try to meet the demands of the principal to get high compensation, if there is no strict supervision from the principal, then the manager can manipulate company data so that the profit target is achieved [22].

With the increase in deferred corporate taxes listed in the financial statements, investors logically will not put an investment in these companies. According [16] if this tax aggressiveness is known to the public, it can have a direct impact on the decline in the company's stock price, so firm value also decreases. Tax aggressiveness has a negative effect on stock prices for companies that are considered more aggressive in tax avoidance [17]. Research which conducted by [20], also implying that tax avoidance has a negative effect on firm value.

However, other researchers ahow that tax aggressiveness has a positive effect on firm value [23], [24], and [25]. The difference in research results may be caused by the different research samples used by those reasearches. Based on this description, the hypothesis regarding the value of the company is:

$\mathrm{H} 2$ : Tax aggressiveness has a negative effect on firm value
This research follows up on previous research [14] and [8] by adding an independent variable in the form of tax aggressiveness. Tax aggressiveness is added in this research because it can be seen from the results of previous studies that many are inconsistent. In conducting research on stock prices, many factors can influence it, including factors that are not examined in this study. This research also uses the period of the political year, namely 2016-2018, because the political year greatly affects stock price movements on the Indonesia Stock Exchange [26].

\section{METHOD}

This research is a quantitative explanatory research that analyzes and explains the relationship of variables, those variables are independent variable $(\mathrm{X})$ political connection and tax aggressiveness with the dependent variable (Y) firm value. This study use mining companies listed on the IDX for the 2016-2018 period. Mining companies were chosen because they require large capital and have close-tie with government regulations regarding mining permits. The research was conducted for 3 years (2016-2018) those year were considered as political years in Indonesia because it led to general election (pemilu). Samples were taken with purposive sampling method selected based on certain criteria according to the objectives as reflected in Table 2.

Table 2. Research Sampling

\begin{tabular}{|l|l|c|}
\hline No & \multicolumn{1}{|c|}{ Criteria } & Amount \\
\hline 1 & $\begin{array}{l}\text { Mining companies consecutively listed } \\
\text { on the IDX in 2016-2018. }\end{array}$ & 42 \\
\hline 2 & $\begin{array}{l}\text { The company did not publish an annual } \\
\text { report during the 2016-2018 period }\end{array}$ & $(9)$ \\
\hline 3 & $\begin{array}{l}\text { The company did not make a profit } \\
\text { during the 2016-2018 period }\end{array}$ & 22 \\
\hline & $\begin{array}{l}\text { Company Samples } \\
\text { Amount of research data: The number of } \\
\text { samples multiplied by the year of } \\
\text { observation (22x3 year) }\end{array}$ & \\
\hline
\end{tabular}

\subsection{Variable Research}

\subsubsection{Dependent Variable}

The dependent variable in this study is firm value, which is the selling price of the company when the company is sold [27]. The formula used to calculate firm value is tobins'Q. The measurement of firm value in this study refers to research [16].

$$
\text { Tobins' } \mathrm{Q}=\frac{E M V+D}{E B V+D}
$$

Information

Tobins' Q : Firm Value

EMV : Equity Market Value 
$\begin{array}{ll}\text { EBV } & : \text { Equity Book Value } \\ \text { D } & : \text { Total Liabilities }\end{array}$

\subsubsection{Independent Variable}

\subsubsection{Political Connection}

Companies that have political connections are seen from the composition of the commissioners / directors and shareholders. Political connection in this study is measured using a dummy variable, where a value of 1 is given to companies that have political connections and a value of 0 is given when companies have no political connections.

The criteria for political connection in this study refer to the research of [28] :

1. The board of directors and/or the board of commissioners has concurrent positions as a politician affiliated with a political party.

2. The board of directors and/or the board of commissioners hold concurrent positions as government officials.

3. The board of directors and/or the board of commissioners hold concurrent positions as military officers.

4. The board of directors and/or the board of commissioners hold concurrent positions as former government officials or former military officers.

\subsubsection{Tax Aggressiveness}

Tax aggressiveness, where tax avoidance acts aggressively to reduce or even eliminate the tax debt that must be paid by the company. The formula used to calculate tax aggressiveness is ETR (Effective Tax Rate). The ETR ratio is used because it involves current tax expense and deferred tax. The measurement of tax aggressiveness in this study refers to research [16] :

$$
\mathrm{ETR}=\frac{\text { Total Tax Expenses }}{\text { Pre Tax Income }}
$$

Information

ETR : Effective Tax Rate

\subsection{Data collection}

Sources of data used in this study are secondary data sourced from the financial statements of mining companies on the IDX for the 2016-2018 period obtained from the IDX website (www.idx.co.id).

\subsection{Data analysis technique}

The data analysis used in this research is multiple linear regression model. The regression model used is as follows: Multiple Linear Regression
This model is used because this study examines the effect of political connections and the level of tax aggressiveness on firm value. Here's the equation model:

$\mathrm{Y}=\mathrm{a}+\beta 1 \mathrm{X} 1-\beta 2 \mathrm{X} 2+\varepsilon$

Information:

$\mathrm{Y}=$ Firm value

$\mathrm{a}=$ Constant

$B 1-B 2=$ regression coefficient

$\mathrm{X} 1=$ Political Connection

$\mathrm{X} 2=$ Tax Aggressiveness

$\varepsilon=$ Error

\section{RESULT}

\subsection{Descriptive statistics}

Descriptive statistics include the dependent variable and the independent variable. These results are contained in Table 2. The minimum value of mining company value is 0.454 for PT Ratu Prabu Energi Tbk in 2017, which indicates that the condition of the share price of PT Ratu Prabu Energi in the market is below the fair price of its shares (undervalued). According to [29], if the company value is below number 1 , it means that investors do not give premium to the emitent.

The maximum value is 4,386 for PT Bayan Resources in 2018 which indicates that the condition of the stock price of PT Bayan Resources in the market is much higher than the fair price of its stock (overvalued) because Tobin's $\mathrm{Q}$ value is more than 1 . The mean of the company value is 1.30608 which indicates the average value of mining companies is high, because the value of Tobin's $\mathrm{Q}$ is more than 1 indicating that the mining company's stock price is above its fair price (overvalued). The standard deviation value of the firm value variable is smaller than the mean. This means that the standard error of this study is low, so the determination of the variables used in this study is good for further investigation.

Table 2. Result of calculation

\begin{tabular}{|l|l|l|l|l|l|}
\hline Info & $\mathrm{N}$ & Min & Max & Mean & Std. Dev \\
\hline ETR & 66 & 0,084 & 1,134 & 0,35118 & 0,171866 \\
\hline KPOL & 66 & 0,454 & 4,386 & 1,30608 & 0,732460 \\
\hline $\begin{array}{l}\text { Valid N } \\
\text { (listwise) }\end{array}$ & 66 & & & & \\
\hline
\end{tabular}

The minimum value of tax aggressiveness as measured by formula ETR (effective tax rate) was 0.084 at PT Ratu Prabu Energi Tbk in 2016, this number indicates that the profit before tax was greater than the deferred tax expense. The maximum value of tax aggressiveness during the study period was 1,134 at PT Surya Esa Perkasa Tbk in 2018, which means that in 
2018 the profit before tax was smaller than the deferred tax expense. The mean of the value of tax aggressiveness was 0.35118 which indicates that the average mining sector company avoids tax, because the lower the ETR value (close to 0), the higher the level of tax aggressiveness a company undertakes [30]. The standard deviation value of the tax aggressiveness variable is smaller than the mean. This implies that the standard error of this study is low, so the determination of the variables used in this study is good for further investigation.

The political connection variable in this study is measured using a dummy variable so that the descriptive statistics are carried out separately in table 3 . Political connections are obtained from the biographical data of the board of directors or commissioners, that the sample companies with political connections are given a value of 1 and companies that have no political connections are given value 0 . From the research results show that $57.58 \%$ of mining sector companies have political connections with the government.

Table 3. Political Connections (X1)

\begin{tabular}{|l|c|c|}
\hline Information & Frequency & Percent \\
\hline KPOL & 38 & $57,58 \%$ \\
\hline Non KPOL & 28 & $42,42 \%$ \\
\hline Total & 66 & $100 \%$ \\
\hline
\end{tabular}

\subsection{Multiple Linear Regression Analysis}

Multiple linear regression is used to find out the connection between political connection tax aggressiveness toward mining sector company's value on IDX (BEI) from 2016-2018. The result could be seen in table 4:

Table 4. Multiple Linear Regression Results

\begin{tabular}{|l|c|c|c|}
\hline \multicolumn{1}{|c|}{ Model } & B & t & Sig. \\
\hline (Constanta) & $-0,129$ & $-0,818$ & 0,416 \\
\hline KPOL & $-0,032$ & $-0,279$ & 0,781 \\
\hline ETR & $-0,274$ & $-2,319$ & 0,024 \\
\hline Adjustes R2 & 0,055 & & \\
\hline
\end{tabular}

\subsubsection{The Effect of Political Connection on Firm Value.}

The test results show that political connections in mining sector companies listed on the IDX have no significant effect on firm value, so this study is unable to reject $\mathrm{H} 0$, so it can be concluded that political connections have no effect on firm value. This can be proven in table 4.9 which shows the probability value $(0.781)>a(0.05)$. So, it can be concluded that political connections do not have a significant effect, so that the presence or absence of political connections that the company has through the board of commissioners and the board of directors does not affect the value of the company in mining sector companies.
These results indicate that political connections cannot be used as a predictor to determine firm value, so that the presence or absence of political connections that a company has through the board of commissioners and the board of directors has no effect on firm value. This can occur because of the tendency of investors to prefer to invest in companies with stable or high profits [31].

Political connections through the board of commissioners and board of directors are not a problem for mining sector companies, because mining sector companies are well-established in Indonesia, so they will not have an impact on company value. In addition, mining sector companies do not have too much competition [32]. In addition, political events make changes in company value tend to be unprofitable and the government does not provide benefits or benefits to companies that are politically connected [15].

In addition, the privilege of obtaining a loan can increase company debt, with the behavior that borrows funds too often results in company profits being used to pay debt not to distribute dividends so that it is not profitable for investors [33], therefore, political connections do not give positive signals to investors.

\subsubsection{The Effect of Tax Aggressiveness on Firm Value}

The results analysis show that the tax activity of the mining deposit companies listed on the IDX has a significant effect on firm value, so this study is able to reject $\mathrm{H} 0$, so it can be concluded that the tax effectiveness affects firm value. This can be proven in table 4.9 which shows the probability value $(0.24)<a$ (0.05). So, it can be concluded that the tax effectiveness has a significant effect, so that companies engaging in tax aggressiveness have a negative effect on firm value in mining sector companies.

The results showed that tax aggressiveness had a negative effect on firm value. These results indicate that tax aggressiveness, which can be in the form of tax planning or tax avoidance, can reduce company value. This happens because investors consider companies that do tax aggressiveness to have a higher risk than companies that do not tax aggressiveness.

According to [18] tax aggressiveness can cause several losses if companies are indicated to take tax aggressiveness. Losses from tax aggressiveness can be in the form of the threat of sanctions or penalties from the tax authorities, either in the form of administrative witnesses or in the form of fines. Based on RI Law no. 9 of 2017, Article 7 paragraph (3) which regulates that the leadership and / or employees of the entity make false statements or hide or reduce financial account information that must be submitted in the report, shall be punished with imprisonment of 1 (one) year or a maximum fine. IDR 1,000.0000.0000,000 (one billion 
rupiah). The act of tax aggressiveness violating taxation rules will reduce shareholders' trust so that it can lower share prices [19], besides tax aggressiveness can lead to a decrease in company value [34]. Therefore, investors prefer to invest in companies that do not engage in tax aggressiveness than companies that do tax aggressiveness.

\section{CONCLUSION}

This study focuses on the influence of political connections and tax aggressiveness on firm value in mining companies in Indonesia in 2016-2018. Based on the tests that have been carried out, there are two conclusions. First, political connections have no effect on firm value, this is because investors tend to not see how close companies are to government officials. In addition, some investors consider companies that have political connections to perform poorly in the political year and the government does not provide benefits or advantages so political events make changes in company value tend to be unprofitable. Second, tax aggressiveness has a negative effect on firm value, this is because investors consider companies that do tax aggressiveness to have a high risk compared to companies that do not do tax aggressiveness. In addition, the act of tax aggressiveness can cause several losses, namely criminal sanctions or penalties from the tax authorities, decreased trust from shareholders so that it can reduce the company's share price which indicates the company's value.

Even though it has contributed in practice, this study has limitations where political connections are only seen from the biographies of the board of directors and commissioners that are presented in the annual report, so that companies that have political connections from indirect relationships such as friendship or family relationships cannot be known. The next research should look for political connections through indirect relationships or the measurement of political connection variables can be replaced by using the share ownership ratio data from the government so that it can produce accurate data.

\section{REFERENCES}

[1] U. Soebiantoro, S. Pengajar, and F. Ekonomi, "Pengaruh Struktur Kepemilikan Saham, Leverage , Faktor Intern Dan Faktor Ekstern Terhadap Nilai Perusahaan ( Studi empirik pada perusahaan manufaktur dan non manufaktur di Bursa Efek Jakarta )," no. 1976, pp. 41-48, 1984.

[2] I. M. Sudana, Manajemen Keuangan Perusahaan Teori \& Praktik. Surabaya: Erlangga, 2011.
[3] E. Rahmayanti, "Indeks Sektor Pertambangan Menguat 53\% Sepanjang 2016, Penompang Utama IHSG," 2016. http://www.bareka.com/id/text/2016/10/17indekssektor-pertambangan-menguat-53-sepanjang-2016penopang-utama-ihsg/14103/analysis

[4] E. Rahmayanti, "Harga Saham Pertambangan Kembali Memerah, Kenapa ?," 2017. http://amp.bareksa.com/en/text/2017/12/06/hargasaham-pertambangan-kembali-memerahkenapa/17667/news

[5] E. L. L. Putri, "Tahun Politik, Ini Saham-Saham yang Perlu Dicermati," 2017. http://amp.kontan.co.id/news/tahun-politik-inisaham-saham-yang-perlu-dicermati

[6] K. Genjar and I. Oktavia, "Faktor-Faktor Yang Mempengaruhi Harga Saham," Semnar Nas. Manaj. dan Bisnis ke-3 Progr. Stud. Manaj. Fak. Ekon. dan Bisnis Univ. Jember, pp. 28-43, 2015.

[7] E. Goldman, J. Rocholl, and J. So, "Politically connected boards of directors and the allocation of procurement contracts," Rev. Financ., vol. 17, no. 5, pp. 1617-1648, 2013.

[8] N. N. Amorita, "Koneksi Politik dan Nilai Perusahaan," 2017.

[9] E. al Song, "Institutional environment, political connections of partial state ownership, and performance," International Journal of Social Economics, Vol. 43, no 8, pp. 856 - 870, 2016.

[10] G. A. Akerlof, “The market for 'lemons': Quality uncertainty and the market mechanism," in Decision Science, 2017.

[11] Wijantini, "A Test of the Relationship Between Political Connection and Indirect Costs of Financial Distress in Indonesia," Asian Acad. Manag. J. Account. Financ., vol. 3, no. 2, pp. 6181, 2007.

[12] M. J. Cooper, H. Gulen, and A. V Ovtchinnikov, "Corporate Political Contributions and Stock Returns,” vol. LXV, no. 2, pp. 687-724, 2010.

[13] I. et Al, "Characteristics of Politically Connected Firms in Indonesia," no. 4, 2017.

[14] M. Faccio, "Politically connected firms," Am. Econ. Rev., vol. 96, no. 1, pp. 369-386, 2006.

[15] H. Berkman and V. Galpoththage, "Political connections and firm value: an analysis of listed firms in Sri Lanka," Pacific Account. Rev., vol. 28, no. 1, pp. 92-106, 2016.

[16] P. N. C. Devi and N. L. Supadmi, "Pengaruh Agresivitas Pajak Pada Nilai Perusahaan Dengan 
Ukuran Perusahaan Sebagai Pemoderasi,” E-Jurnal Akunt., vol. 22, p. 2257, 2018.

[17] M. Hanlon and J. Slemrod, "What does tax aggressiveness signal? Evidence from stock price reactions to news about tax shelter involvement 㶦, "J. Public Econ., vol. 93, no. 1-2, pp. 126-141, 2009.

[18] S. Chen, X. Chen, Q. Cheng, and T. Shevlin, “Are family firms more tax aggressive than non-family firms?," J. financ. econ., vol. 95, no. 1, pp. 41-61, 2010.

[19] G. Jiang, C. M. C. Lee, and H. Yue, "Tunneling through intercorporate loans: The China experience," J. financ. econ., vol. 98, no. 1, pp. 120, 2010 .

[20] M. C. Jensen and W. H. Meckling, "Theory of the Firm: Managerial Behavior, Agency Costs and Ownership Structure Theory of the Firm: Managerial Behavior , Agency Costs and Ownership Structure," 1976.

[21] M. Ridha and D. Martani, "BF-B2c2-5-AnalisisTerhadap-Agresivitas...-Dwi-Martani.pdf,” 2017.

[22] R. Anggraeni, "Pengaruh Koneksi Politik Terhadap Tax Aggressiveness (Studi empiris: Perusahaan Manufaktur yang Terdaftar di Bursa Efek Indonesia Tahun 2014-2017),” 2011.

[23] N. Lestari, "Pengaruh Tax Planning," Akuntabilitas, vol. VII, no. 1, pp. 69-83, 2014.

[24] A. F. Kurniawan and M. Syafruddin, "Pengaruh penghindaran pajak terhadap nilai perusahaan dengan variabel moderasi transparansi," Diponegoro J. Account., vol. 6, no. 4, pp. 1-10, 2017.

[25] A. A. Dewi and L. G. K. Dewi, "Transparasi Informasi Memoderasi Pengaruh Agresivitas Pajak Pada Nilai Perusahaan Pertambangan di Bursa Efek Indonesia" J. Ilmu Akunt., vol. 10, no. 2, pp. 211-230, 2017.

[26] M. Samsul, Pasar Modal Dan Manajemen Portofolio. Surabaya: Erlangga, 2006.

[27] B. Sugeng, Manajemen Keuangan Perusahaan. Yogyakarta: Deepublish, 2012.

[28] T. Wulandari, “Analisis Pengaruh Political Connection Dan Struktur Kepemilikan Terhadap Kinerja Perusahaan," Diponegoro J. Account, vol. 2, pp. 141-152, 2013.

[29] J. F. Weston and E. C. Thomas, Manajemen Keuangan. Jakarta: Binarupa Aksara, 2010.
[30] Luke and Zulaikha, "Analisis Faktor Yang Mempengaruhi Agresivitas Pajak (Studi Empiris Pada Perusahaan Manufaktur Yang Terdaftar di Bursa Efek Indonesia Pada Tahun 2012-2014),” J. Akunt. Audit., vol. 13, no. 1, pp. 80-96, 2016.

[31] A. Tarihoran, "Pengaruh Penghindaran Pajak Dan Leverage Terhadap Nilai Perusahaan Dengan Transparansi Perusahaan Sebagai Variabel Moderasi," J. Wira Ekon. Mikroskil, vol. 6, no. 2, pp. 149-164, 2016.

[32] L. Wulandari, "Pengaruh Political Connection Pada Dewan Komisaris dan Dewan Direksi Terhadap Kinerja Perusahaan Sektor Pertambangan Yang Terdaftar di Bursa Efek Indonesia (BEI) Periode Tahun 2010-2014," J. Ilm. Mhs. Univ. Surabaya, vol. 7, no. 1, pp. 1196-1226, 2018.

[33] M. R. Dewanti, "Pengaruh koneksi politik terhadap nilai perusahaan yang terdaftar di bei," 2019.

[34] N. Shaipah, A. Wahab, and K. Holland, "Tax planning, corporate governance and equity value," Br. Account. Rev., vol. 44, no. 2, pp. 111-124, 2012. 